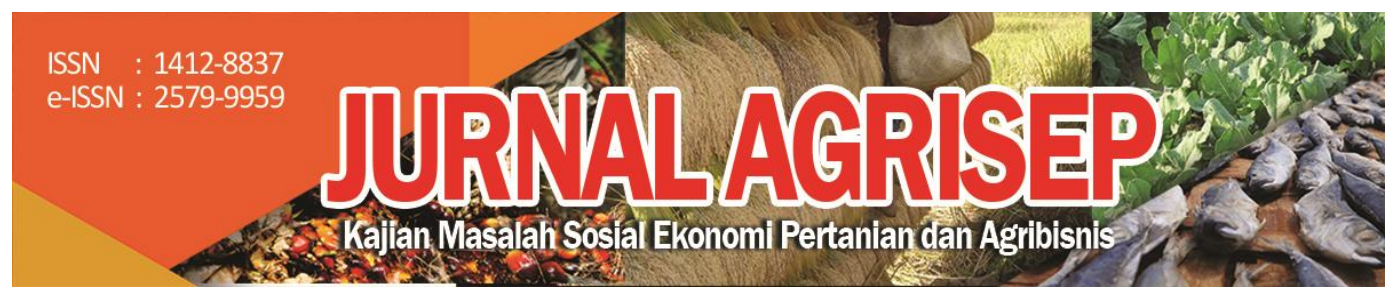

DOI: 10.31186/jagrisep.19.1.191-206

\title{
NILAI TAMBAH DAN KEBERLANJUTAN USAHA PENGOLAHAN PISANG DI KECAMATAN CURUP TENGAH KABUPATEN REJANG LEBONG \\ (Studi Kasus Pisang Sari Gizi Kamiso Karto)
}

\section{Value Added And Sustainability Of Banana Processing Business In Curup Tengah Sub-Districk Of Rejang Lebong Regency \\ (A Case Study Of Bananas Sari Gizi Kamiso Karto)}

\author{
Atin Utami ${ }^{1} \square$, Satria Putra Utama ${ }^{2)}$, Putri Suci Asriani ${ }^{3)}$ \\ Jurusan Sosial Ekonomi Pertanian Fakultas Pertanian Universitas Bengkulu \\ Email: atinutami25@gmail.com
}

\begin{abstract}
The objective of the research were to : (1) calculate and analyze the value added generated from the banana processing bussiness Sari Gizi Kamiso Karto in Curup Tengah Sub-District of Rejang Lebong Regency, (2) know and analyze the sustainability level of banana processing Bussiness Sari Gizi Kamiso Karto in Curup Tengah SubDistrict Of Rejang Lebong Regency. The research were used primary data and secondary data. Data analysis included value added analysis with Hayami Method, to determine the sustainability of the bussiness conducted a descriptive study that can be seen from the ratio of added value, labor market and profit levels. The results showed that : (1) the amount of value added obtained from the production of banana ambon into pisang sale and pisang kepok became banana chips that were equal to $R p 37.625,52 / \mathrm{kg}$ and $R p .27 .877,24 / \mathrm{kg}$ (2) based on calculations using Hayami Method by looking the indicators of bussiness sustainability on banana sale products and banana chips has a high level of bussiness sustainability.
\end{abstract}

Keywords : value added, bussiness sustainability, banana sale, banana chips

\section{ABSTRAK}

Tujuan penelitian ini adalah: (1) menghitung dan menganalisis nilai tambah yang dihasilkan dari usaha pengolahan pisang Sari Gizi Kamiso Karto di Kecamatan Curup Tengah Kabupaten Rejang Lebong, (2) mengetahui dan menganalisis tingkat keberlanjutan pengolahan pisang. Bisnis Sari Gizi Kamiso Karto terletak di Curup 
Tengah, Kecamatan Rejang Lebong. Penelitian ini menggunakan data primer dan data sekunder. Analisis data meliputi analisis nilai tambah dengan Metode Hayami, untuk mengetahui keberlanjutan usaha dilakukan penelitian deskriptif yang dapat dilihat dari rasio nilai tambah, pangsa tenaga kerja, dan tingkat keuntungan. Hasil penelitian menunjukkan bahwa: (1) jumlah nilai tambah yang diperoleh dari produksi pisang ambon menjadi pisang sale dan pisang kepok menjadi keripik pisang yaitu sebesar Rp $37.625,52$ / kg dan Rp.27.877,24 / kg (2) berdasarkan hasil perhitungan menggunakan Metode Hayami dengan melihat indikator keberlanjutan usaha pada produk pisang sale dan keripik pisang memiliki tingkat keberlanjutan usaha yang tinggi.

Kata kunci: nilai tambah, keberlanjutan usaha, pisang sale, keripik pisang

\section{PENDAHULUAN}

Buah-buahan merupakan kelompok komoditas pertanian yang mampu menghasilkan PDB tertinggi dibandingkan kelompok komoditas lainnya dalam subsektor hortikultura (Direktorat Jenderal Hortikultura, 2014). Indonesia memiliki struktur perekonomian agraris yang harus memperkokoh sektor pertanian melalui strategi pengembangan sektor pertanian yang tangguh. Pengembangan agribisnis sebagai salah satu strategi pembangunan pertanian merupakan suatu upaya untuk mencapai beberapa tujuan, diantaranya adalah mendorong tumbuhnya industri baru di sektor pertanian, menciptakan nilai tambah, menciptakan lapangan kerja dan memperbaiki distribusi pendapatan, serta efisiensi. Pengembangan agroindustri merupakan salah satu upaya untuk meningkatkan nilai tambah produk komoditas pertanian dan dapat mengubah sistem pertanian tradisional menjadi lebih maju (Bagus, 2016).

Kabupaten Rejang Lebong merupakan daerah penghasil pisang terbesar di Provinsi Bengkulu. Hal ini terlihat dari jumlah produksi tertinggi yang dicapai Rejang Lebong pada tahun 2015 yaitu sebesar 95.151 ton atau 39,65\% dari total produksi di Provinsi Bengkulu. Berdasarkan kondisi tersebut dilakukannya pengolahan buah pisang.

Pengembangan usaha pengolahan pisang ambon menjadi sale pisang dan pisang kepok menjadi keripik pisang di Kabupaten Rejang Lebong terdapat di Kecamatan Curup Tengah, tepatnya di Jl. Cokro Aminoto No. 68 A Kelurahan Sidorejo. Usaha pengolahan pisang ini bernama "Sari Gizi Kamiso Karto". Jenis pisang yang paling sering digunakan sebagai olahan adalah pisang ambon. Pisang ambon Curup memiliki kulit yang halus berwarna hijau atau kuning dengan daging putih yang manis dan tidak berbiji. Ukuran pisang ambon cukup besar. Pemilihan jenis pisang ambon sebagai bahan baku utama dikarenakan pisang ambon memiliki rasa yang manis dan aroma yang wangi. Selain itu, pisang ambon banyak tersedia di daerah Curup. Pada industri pengolahan pisang Sari Gizi Kamiso Karto pisang ambon diolah menjadi sale pisang dan kripik pisang. 
Industri pengolahah pisang Sari Gizi Kamiso Karto melakukan pengolahan pisang ambon menjadi sale pisang dan pisang kepok menjadi keripik pisang. Sale Pisang merupakan salah satu produk olahan pisang ambon siap konsumsi yang diolah melalui proses pengeringan matahari maupun pemanggangan. Sale Pisang dikenal mempunyai rasa dan aroma yang khas. Sale Pisang Curup memiliki banyak keunggulan diantaranya adalah memiliki rasa yang manis, aroma yang khas, tebal namun tetap renyah, dan tanpa menggunakan bahan pengawet. Pada dasarnya hampir semua jenis pisang dapat dijadikan olahan sale, akan tetapi ada beberapa pisang yang memiliki rasa sepet meskipun telah matang, sehingga tidak cocok untuk digunakan dalam pengolahan sale pisang. Selain itu industri pengolahan Sari Gizi Kamiso Karto juga mengolah pisang kepok menjadi Keripik Pisang, yaitu olahan pisang dengan proses pengirisan tipis buah pisang kemudian dilanjutkan dengan proses penggorengan. Keripik pisang memiliki dua rasa yaitu manis dan gurih/asin.

Pengolahan pisang ambon segar menjadi sale pisang dan pisang kepok menjadi keripik pisang mampu menciptakan nilai tambah (value added). Produk olahan yang dihasilkan berupa sale pisang dan keripik pisang akan dapat bertahan lebih lama dan rantai pemasarannya akan lebih panjang dengan cakupan pasar yang lebih luas. Demi kelanjutan usaha ini diperlukan kepastian usaha yang menguntungkan bagi perusahaan. Kepastian usaha tersebut dapat diketahui melalui berapa nilai tambah yang dapat diciptakan dari kedua produk tersebut dan berapa tingkat keberlanjutan usaha yang mampu dicapai

Berdasarkan latar belakang tersebut dapat dirumuskan permasalahan yang diteliti adalah : (1) Berapa nilai tambah yang dihasilkan dari usaha pengolahan Pisang Sari Gizi Kamiso Karto di Kecamatan Curup Tengah Kabupaten Rejang Lebong?. (2) Bagaimana tingkat keberlanjutan usaha pengolahan pisang Sari Gizi Kamiso Karto di Kecamatan Curup Tengan Kabupaten Rejang Lebong?. Adapun tujuan dilaksanakan penelitian ini adalah untuk : (1) Menghitung dan menganalisis nilai tambah yang dihasilkan dari usaha pengolahan Pisang Sari Gizi Kamiso Karto di Kecamatan Curup Tengah Kabupaten Rejang Lebong, (2) Mengetahui dan menganalisis tingkat keberlanjutan usaha pengolahan Pisang Sari Gizi Kamiso Karto di Kecamatan Curup Tengah Kabupaten Rejang Lebong.

\section{METODE PENELITIAN}

Penelitian ini dilaksanakan di Industri Sari Gizi Kamiso Karto yang beralamat di Jl. Cokro Aminoto No. 68 A Kelurahan Sidorejo Kecamatan Curup Tengah, Kabupaten Rejang Lebong dari bulan Februari sampai Maret 2017. Data yang digunakan dalam penelitian ini adalah data primer dan data sekunder. Data primer yaitu data yang diperoleh secara langsung dari sumber asli atau pertama (Narimawati, 2008), meliputi sejarah perusahaan, identitas responden, 
input produksi dan data kepemilikan alat-alat produksi. Data sekunder yaitu publikasi instansi-instansi yang berkaitan dengan penelitian (Sugiyono, 2013).

\section{Metode Analisis Data}

\section{Analisis Nilai Tambah}

Perhitungan nilai tambah produk olahan pisang menggunakan Metode Hayami yang dihitung berdasarkan harga yang berlaku pada tahun analisis (Hayami, 1987).

\section{Keberlanjutan Usaha}

Berdasarkan hasil perhitungan nilai tambah, dilakukan kajian deskriptif untuk menentukan keberlanjutan usaha. Beberapa indikator keberlanjutan usaha yang digunakan dari hasil perhitungan, adalah: 1) rasio nilai tambah yaitu kemampuan perusahaan untuk menciptakan keuntungan, 2) pangsa tenaga kerja yaitu kemampuan perusahaan untuk menciptakan lapangan kerja, dan 3) tingkat keuntungan yaitu kemampuan menciptakan tingkat keuntungan.

Berikut skala indikator keberlanjutan usaha (Ustriyana, 2018), yang terdiri dari : rasio nilai tambah, pangsa tenaga kerja, dan tingkat keuntungan ; $0 \%-33$ $\%=$ Rendah; $34 \%-66 \%=$ Sedang; $67 \%-100 \%=$ Tinggi.

\section{HASIL DAN PEMBAHASAN}

\section{Karakteristik Tenaga Kerja}

Data tenaga kerja diambil dari semua karyawan yang bekerja di Industri Pengolahan Pisang Sari Gizi Kamiso Karto, disajikan pada Tabel 1.

Tabel 1. Data Tenaga Kerja Industri Pengolahan Pisang Sari Gizi Kamiso Karto

\begin{tabular}{clccc}
\hline No & Nama & Jenis Kelamin & Umur(Th) & Pendidikan \\
\hline 1 & Sol & $\mathrm{P}$ & 50 & SD \\
2 & Ahmad Soleh & $\mathrm{L}$ & 35 & SMP \\
3 & Nur & $\mathrm{P}$ & 19 & SD \\
4 & Herman & $\mathrm{L}$ & 25 & SMP \\
5 & Noviyanti & $\mathrm{P}$ & 35 & MAN \\
\hline
\end{tabular}

Sumber: Diolah dari data primer 2018

Pada Tabel 1, dapat dilihat bahwa umur tenaga kerja di Industri Pengolahan Pisang Sari Gizi Kamiso Karto berkisar antara 19-50 tahun, hal ini merupakan kelompok produktif yang menandakan proses pengolahan oleh tenaga kerja dapat dilakukan secara optimal. Pendidikan yang ditempuh juga 
beragam ada dua pekerja yang hanya tamat SD, dua pekerja yang tamat SMP, dan satu tamat MAN. Upah tenaga kerja pada industri pengolahan Sari Gizi Kamiso Karto dibayarkan perhari, yaitu sebesar Rp. 50.000,- .

\section{Analisis Nilai Tambah Sale Pisang dan Keripik Pisang}

Perhitungan nilai tambah pada proses pengolahan pisang ambon menjadi sale pisang dan pisang kepok menjadi keripik pisang digunakan untuk mengetahui seberapa besar nilai tambah yang mampu dihasilkan dari pengolahan buah pisang tersebut.

Analisis nilai tambah dalam penelitian ini menggunakan Metode Hayami. Dalam Industri Pengolahan Sari Gizi Kamiso Karto ada dua produk yang dianalisis yaitu produk sale pisang dan keripik pisang. Analisis nilai tambah yang dilakukan pada penelitian ini dimulai dari pengadaan bahan baku pisang ambon dan pisang kepok sampai dengan menjadi produk olahan yaitu sale pisang dan keripik pisang yang dapat dipasarkan. Perhitungan dalam analisis nilai tambah menggunakan satuan per kilogram pisang ambon dan pisang kepok dengan produk sale dan keripik pisang. Dari analisis nilai tambah tersebut maka akan diketahui produk mana yang menghasilkan nilai tambah yang lebih besar, selain itu juga memberikan infromasi mengenai bagian persentase keuntungan, tenaga kerja dan bagaian input lain. Pada Tabel 2, dapat dilihat hasil perhitungan nilai tambah dengan Metode Hayami dari kedua produk tersebut.

\section{Output, Input dan Harga}

Berdasarkan Tabel 2, penggunaan bahan baku per priode produksi ratarata menggunakan pisang ambon sebanyak $50 \mathrm{Kg}$ dan menghasilkan sale pisang sebanyak $35 \mathrm{Kg}$. Pada bahan baku pisang kepok sebanyak $50 \mathrm{Kg}$ menghasilkan $30 \mathrm{Kg}$ keripik pisang. Pengurangan hasil output dikarenakan sale pisang mengalami penyusutan pada saat pengupasan kulit dan penjemuran, sedangkan keripik pisang asin maupun manis mengalami penyusutan pada saat pengupasan kulit dan penggorengan.

Tenaga kerja yang digunakan dalam proses pengolahan sale pisang dan keripik pisang berjumlah 5 orang yang bekerja secara bergantian. Sistem upah yang diberikan adalah dengan pembayaran harian yaitu sebesar Rp.50.000/hari.

Besarnya upah tenaga kerja di industri sejenis di Kota Palu Provinsi Sulawesi Tengah berdasarkan hasil penelitian Anggraini (2013), yang berjudul "Analisis Usaha dan Nilai Tambah Industri Olahan Pisang di Kota Palu Provinsi Sulawesi Tengah", yaitu sebesar Rp. 50.000/hari, upah ini sama dengan upah yang diberikan pada Industri Sari Gizi Kamiso Karto, besaran angka upah ini mempengaruhi besar kecilnya jumlah tenaga kerja yang digunakan. 
Tabel 2. Data Perhitungan Nilai Tambah Dengan Menggunakan Metode Hayami Industri Sari Gizi Kamiso Karto

\begin{tabular}{|c|c|c|c|c|}
\hline \multirow{2}{*}{ Output, Input dan Harga } & \multirow{2}{*}{ Rumus } & \multirow{2}{*}{$\begin{array}{c}\text { Sale } \\
\text { Pisang }\end{array}$} & \multicolumn{2}{|c|}{ Keripik Pisang } \\
\hline & & & Manis & Asin \\
\hline 1. Output (kg) & $\mathrm{a}$ & 35 & 15 & 15 \\
\hline 2. Input (kg) & $\mathrm{b}$ & 50 & 25 & 25 \\
\hline 3. Tenaga Kerja (HOK) & c & 6,75 & 1 & 1 \\
\hline 4. Faktor Konversi & $d=a / b$ & 0,70 & 0,60 & 0,60 \\
\hline 5. Koefisien Tenaga Kerja (HOK/kg) & $e=c / b$ & 0,14 & 0,04 & 0,04 \\
\hline 6. Harga Output (Rp/kg) & $\mathrm{f}$ & 60.000 & 55.000 & 55.000 \\
\hline 7. Upah Tenaga Kerja (Rp/HOK) & $\mathrm{g}$ & 50.000 & 50.000 & 50.000 \\
\hline $\begin{array}{l}\text { Penerimaan dan Keuntungan } \\
\text { (Rp/kg) }\end{array}$ & & & & \\
\hline 8. Harga Bahan Baku (Rp/kg) & $\mathrm{h}$ & 2.500 & 1.800 & $1.800,00$ \\
\hline 9. Sumbangan input lain $(\mathrm{Rp} / \mathrm{kg})$ & $\mathrm{i}$ & $1.878,77$ & $6.480,72$ & $4.413,72$ \\
\hline 10. Nilai Output $(\mathrm{Rp} / \mathrm{kg})$ & $j=d \times f$ & $42.000,00$ & $33.000,00$ & $33.000,00$ \\
\hline 11. a. Nilai Tambah (Rp/kg) & $\mathrm{k}=\mathrm{j}-\mathrm{i}-\mathrm{h}$ & $37.621,23$ & $24.719,28$ & $26.786,28$ \\
\hline b. Rasio Nilai Tambah (\%) & $1=(\mathrm{k} / \mathrm{j}) \times 100 \%$ & 89,57 & 74,91 & 81,17 \\
\hline 12. a. Pendapatan tenaga kerja (Rp/kg) & $\mathrm{m}=\mathrm{e} \times \mathrm{g}$ & $7.000,00$ & $2.000,00$ & $2 . .000,00$ \\
\hline b. Pangsa tenaga kerja (\%) & $\mathrm{n} \%=(\mathrm{m} / \mathrm{k}) \times 100 \%$ & 18,61 & 8,09 & 7,47 \\
\hline 13. a. Keuntungan $(\mathrm{Rp} / \mathrm{kg})$ & $\mathrm{o}=\mathrm{k}-\mathrm{m}$ & $30.621,23$ & $22.719,28$ & $24.786,28$ \\
\hline b. Tingkat Keuntungan (\%) & $\mathrm{p} \%=(\mathrm{o} / \mathrm{k}) \times 100 \%$ & 81,39 & 91,91 & 92,53 \\
\hline $\begin{array}{l}\text { Balas Jasa Pemilik Faktor } \\
\text { Produksi }\end{array}$ & & & & \\
\hline 14. Marjin (Rp/kg) & $q=j-h$ & $39.500,00$ & $31.200,00$ & $31.200,00$ \\
\hline 15. Keuntungan (\%) & $\mathrm{r}=\mathrm{o} / \mathrm{q} \times 100 \%$ & 77,52 & 72,82 & 79,44 \\
\hline 16. Tenaga Kerja (\%) & $\mathrm{s}=\mathrm{m} / \mathrm{q} \times 100 \%$ & 17,72 & 6,41 & 6,41 \\
\hline 17. Input lain (\%) & $t=i / q \times 100 \%$ & 4,76 & 20,77 & 14,15 \\
\hline
\end{tabular}

Sumber: Diolah dari data primer 2018

Aktivitas yang dikerjakan tenaga kerja pada proses pengolahan sale dan keripik sama, yaitu: mengupas, mengiris, menjemur, menggoreng, dan mengemas. Proses pengolahan sale pisang mulai dari pengupasan sampai dengan pengemasan yaitu sebesar 6,75 HOK dan keripik pisang manis dan asin masing-masing sebesar $1 \mathrm{HOK}$. 
Faktor konversi menunjukkan seberapa besar kemampuan input berupa bahan baku pisang yang digunakan untuk menghasilkan output berupa produk sale pisang dan keripik. Faktor konversi sale pisang lebih besar daripada keripik pisang yaitu 0,70 yang artinya setiap $1 \mathrm{Kg}$ pisang ambon yang diolah akan menghasilkan $0,70 \mathrm{Kg}$ sale pisang. Sedangkan untuk produk keripik pisang manis dan asin faktor konversi sebesar 0,60 artinya setiap $1 \mathrm{Kg}$ pisang kepok yang diolah akan menghasilkan $0,60 \mathrm{Kg}$ keripik pisang. Besarnya nilai faktor konversi di industri sejenis di Kota Palu Provinsi Sulawesi Tengah berdasarkan hasil penelitian Anggraini (2013), adalah 0,40 untuk produk sale pisang dan 0,30 untuk produk keripik pisang, besarnya faktor konversi setelah dibandingkan dari dua produk yang sama pada industri yang berbeda yaitu sama, bahwa faktor konversi sale pisang lebih tinggi dibandingkan keripik pisang. Perbedaan faktor konversi antara industri Sari Gizi Kamiso Karto dan industri yang ada di Kota Palu dikarenakan Kota Palu merupakan dataran rendah sehingga suhu yang dihasilkan lebih panas dan mengasilkan sale pisang yang lebih kering, dibandingkan dengan sale yang ada di Industri Sari Gizi Kamiso Karto yang merupakan dataran tinggi sehingga sale yang dihasilkan lebih lembab. Hal lain yang menyebabkan perbedaan faktor konversi pada keripik pisang adalah jenis pisang yang digunakan, pada industri Sari Gizi Kamiso Karto pisang yang digunakan adalah pisang kepok sedangkan jenis pisang yang digunakan pada industri di Kota Palu adalah pisang tanduk.

Koefisien tenaga kerja adalah rasio antara jumlah Hari Orang Kerja (HOK) dengan jumlah input yang digunakan $(\mathrm{kg})$, besarnya nilai koefisien tenaga kerja menggambarkan besarnya sumbangan tenaga kerja yang dibutuhkan untuk mengolah $1 \mathrm{Kg}$ pisang ambon sampai menjadi sale pisang dan $1 \mathrm{Kg}$ pisang kepok sampai menjadi keripik pisang. Nilai koefisien tenaga kerja pada produk sale pisang yaitu sebesar 0,14 , artinya untuk mengolah masingmasing $1 \mathrm{Kg}$ produk sale pisang membutuhkan tenaga kerja 0,14 HOK. Sedangkan nilai koefisien tenaga kerja pada keripik pisang manis dan asin adalah sebesar 0,04, artinya untuk mengolah $1 \mathrm{Kg}$ pisang kepok menjadi keripik pisang membutuhkan tenaga kerja 0,04 HOK.

Besarnya nilai koefisien tenaga kerja pada industri yang ada di Kabupaten Banyumas berdasarkan hasil penelitian dari Mulyani (2011), yang berjudul "Nilai Tambah Agroindustri Kripik Pisang di Kecamatan Cilongok, Kabupaten Banyumas", yaitu sebesar 0,04 HOK/Kg, nilai ini menunjukkan bahwa pada proses produksi keripik pisang rata-rata HOK yang dibutuhkan untuk mengolah setiap kilogram bahan baku utama pisang adalah 0,04 HOK. Besarnya nilai koefisien tenaga kerja pada industri ini sama dengan besarnya nilai koefisien tenaga kerja yang ada di Industri Sari Gizi Kamiso Karto, artinya kemampuan tenaga kerja yang ada di Industri Sari Gizi Kamiso Karto dan Industri yang ada di Banyumas dalam mengolah input sama yaitu 0,04. Besarnya koefisien tenaga kerja berdasarkan hasil penelitian Anggraini (2013), pada 
produk sale pisang adalah sebesar 0,012 HOK, nilai ini lebih kecil dibanding nilai koefisien tenaga kerja yang ada di Industri Sari Gizi Kamiso Karto, hal ini dikarenakan pengolahan sale dilakukan dua kali dalam sebulan dan tenaga kerja yang di gunakan di Industri Sari Gizi Kamiso Karto juga lebih terampil dalam bekerja.

Harga Output pada Industri Sari Gizi Kamiso Karto yaitu sale pisang adalah Rp. 60.000/Kg dan Keripik Pisang Manis dan Keripik Pisang Asin masing-masing Rp. 55.000/Kg. Besarnya harga output pada produk keripik pisang di Kota Mataram berdasarkan hasil penelitian Bagus (2016), yang berjudul "Analisis Nilai Tambah (Value Added) Buah Pisang Menjadi Kripik Pisang di Kelurahan Babakan Kota Mataram (Studi Kasus Pada Industri Rumah Tangga Kripik Pisang Cakra)", adalah sebesar Rp. 115.500/Kg, harga output yang ditawarkan pada Industri Cakra lebih tinggi dibandingkan pada industri Sari Gizi Kamiso Karto hal ini dikarenakan harga bahan baku pada industri cakra lebih tinggi yaitu Rp. 15.000/Kg sedangkan pada Industri Sari Gizi Kamiso Karto Harga Bahan Baku adalah Rp. 1.800/Kg, murahnya harga bahan baku pada industri Sari Gizi Kamiso Karto dikarenakan melimpahnya jumlah pisang yang ada di Kota Curup. Hal inilah yang menyebabkan tingginya harga output pada industri Cakra dibandingkan pada Industri Sari Gizi Kamiso Karto.

Upah tenaga kerja adalah jumlah upah rata-rata yang diterima oleh pekerja dalam setiap satu priode produksi yang dihitung berdasarkan per HOK. Upah pada proses pengolahan sale sebesar Rp. 50.000/HOK dan keripik pisang sebesar Rp. 50.000/ HOK. Tingginya upah pada proses produksi sale pisang dikarenakan pada pengolahan sale pisang proses yang ditempuh lebih panjang yaitu melakukan penjemuran dan membolak-balik pisang setiap harinya selama 2-3 hari sesuai dengan cuaca.

Besarnya upah tenaga kerja di industri sejenis di Kota Palu Provinsi Sulawesi Tengah berdasarkan hasil penelitian Anggraini (2013), Rp.50.000/HOK. Upah yang digunakan pada industri ini sama dengan upah pada produksi di Industri Sari Gizi Kamiso Karto, hal ini dikarenakan jenis pekerjaan yang dikerjakan sama, sehingga upah yang dihasilkan juga sama.

\section{Penerimaan dan Keuntungan}

Harga bahan baku adalah harga pembelian bahan baku yaitu pisang ambon untuk pengolahan sale dan pisang kepok untuk pengolahan keripik. Harga $1 \mathrm{Kg}$ pisang ambon adalah Rp. 2.500 dan harga $1 \mathrm{Kg}$ pisang kepok adalah Rp. 1.800. Pada bahan baku pisang kepok sebanyak $50 \mathrm{Kg}$ menghasilkan $15 \mathrm{Kg}$ keripik pisang asin dan $15 \mathrm{Kg}$ Keripik Pisang manis. Harga $1 \mathrm{Kg}$ pisang kepok adalah Rp. 1.800., besarnya harga bahan baku pada industri sejenis di Kota Palu Provinsi Sulawesi Tengah berdasarkan hasil penelitian Anggraini (2013), adalah sebesar Rp. 3.172,-/Kg pisang ambon untuk pembuatan sale pisang dan Rp.6.851,-/Kg pisang tanduk untuk pembuatan keripik pisang. Harga pisang 
ambon pada industri Sari Gizi Kamiso Karto lebih murah dibandingkan dengan industri yang ada di Kota Palu, hal ini dikarenakan melimpahnya buah pisang ambon di Kota Curup yang merupakan tempat berdiri industri Sari Gizi Kamiso Karto sehingga harga yang ditawarkan menjadi murah.

Sumbangan input lain yaitu akumulasi dari biaya bahan penolong, penyusutan alat, pemakaian listrik, kemasan dan bahan bakar. Nilai sumbangan input lain pada produk sale pisang sebesar Rp.1.878,77/Kg dan pada produk keripik pisang rasa manis sebesar Rp.6.480,72/Kg dan keripik pisang rasa asin Rp. 4.413,72/Kg. Besarnya sumbangan input lain pada industri sejenis di Kota Palu Provinsi Sulawesi Tengah berdasarkan hasil penelitian Anggraini (2013), adalah sebesar Rp. 1.713.670,-/ bulan dengan dua kali produksi sale pisang, dan Rp.13.505.263,-/bulan dengan 13 kali produksi keripik pisang, sehingga sumbangan input lain yang digunakan dalam setiap proses produksi adalah Rp.12.625,58/Kg produksi sale dan Rp. 38.333,46-/Kg keripik. Sumbangan input lain pada industri ini meliputi biaya kemasan, label, lilin, transportasi, biaya listrik dan biaya bahan bakar. Pada industri ini terdapat biaya transportasi karena pemasaran banyak disalurkan ke pedang-pedagang besar yang ada di Kota Palu. Bahan bakar yang digunakan pada industri yang ada di Kota Palu adalah Gas LPG, sedangkan pada Industri Sari Gizi Kamiso Karto menggunakan kayu bakar. Harga gas LPG lebih mahal dibandingkan dengan harga kayu bakar, inilah yang menyebabkan lebih besarnya sumbangan input lain di industri Kota Palu lebih tinggi.

Nilai output adalah nilai produk yang dihasilkan setelah diperhitungkan besarnya kemampuan input menghasilkan output. Nilai output merupakan hasil perkalian antara faktor konversi degan harga output. Nilai ouput pada masing-masing produk sale pisang dan keripik pisang adalah sebesar Rp.42.000 /Kg dan Rp.33.000/Kg. Artinya nilai sesungguhnya dari produk sale pisang adalah sebesar Rp. 42.000 dan nilai sesungguhnya dari keripik pisang adalah sebesar Rp.33.000/Kg.

Nilai Tambah adalah besarnya penambahan nilai output yang di dapatkan dari adanya proses pengolahan, awalnya input kemudian berubah menjadi output yang baru dan mampu memberikan penambahan nilai. Diperoleh dari Nilai output dikurangi sumbangan input lain dikurangi harga input. Nilai tambah yang dihasilkan dari produk sale pisang adalah sebesar Rp.37.621,23/Kg dan keripik pisang rasa manis adalah sebesar Rp.24.719,28/Kg, dan keripik pisang asin sebesar Rp. 26.786,28/Kg, Artinya setiap pengolahan 1 (satu) $\mathrm{Kg}$ input pisang ambon mampu menghasilkan nilai tambah sale sebesar Rp.37.621,23/Kg sedangkan pada 1 (satu) $\mathrm{Kg}$ input pisang kepok mampu menghasilkan produk keripik pisang manis sebesar Rp.24.719,28/Kg dan keripik pisang asin sebesar Rp. 26.786,28/Kg. Besarnya nilai tambah pada industri sejenis di Kota Palu Provinsi Sulawesi Tengah berdasarkan hasil penelitian Anggraini (2013), adalah sebesar Rp.22.890,-/Kg untuk produk sale 
pisang dan Rp.14.334,-/Kg untuk produk keripik pisang, besarnya nilai tambah yang dihasilkan pada produk sale lebih tinggi dibandingkan pada produk keripik pisang, keadaan ini sama dengan pada industri Sari Gizi Kamiso Karto, namun pada industri di Kota Palu nilai tambah yang dihasilkan lebih rendah, dikarenakan mahalnya harga bahan baku dan sumbangan input lain lebih tinggi.

Rasio nilai tambah adalah persentase dari hasil nilai tambah. Rasio nilai tambah merupakan perbandingan antara nilai tambah dengan nilai output. Pada perhitungan menggunakan Metode Hayami rasio nilai tambah sale pisang dan keripik pisang pada Industri Sari Gizi Kamiso Karto adalah 89,57\% untuk sale pisang dan $74,91 \%$ untuk keripik pisang rasa manis dan $81,17 \%$ keripik rasa asin, dari hasil perhitungan tersebut dapat disimpulkan bahwa usaha Pengolahan Sari Gisi Kamiso Karto layak untuk semakin dikembangkan kedepannya. Menurut Hubeis dalam Purnamasari (2017) rasio nilai tambah dapat digolongkan menjadi 3 kelas, yaitu : Rendah, (apabila < 15\%), Sedang (apabila 15\% - 40\%), dan Tinggi,(apabila > 40\%).

Rasio nilai tambah pada industri Pengolahan Sari Gizi Kamiso Karto tergolong pada kategori tinggi karena memiliki rasio nilai tambah sebesar 89,57\% produk sale pisang, $74,93 \%$ untuk keripik pisang rasa manis dan $81,20 \%$ keripik rasa asin. Besarnya nilai tambah pada industri sejenis di Kota Palu Provinsi Sulawesi Tengah berdasarkan hasil penelitian Anggraini (2013), adalah 75,28 \% untuk produk sale pisang dan 55,09 \% untuk produk keripik pisang. Rasio nilai tambah pada produk sale pisang lebih tinggi dibanding pada produk keripik pisang, keadaan ini sama dengan pada industri Sari Gizi Kamiso Karto. Pada industri Sari Gizi Kamiso Karto Rasio nilai tambahnya adalah sebesar 87,03\%, $71,30 \%$, dan $77,56 \%$. Membedakan nilai tambah dua produk hilir berbeda, merupakan perbandingan jika dijual mentah dan dibandingkan jika sudah mendapatkan sentuhan teknologi pada produk hilir, seterusnya akan memberikan keuntungan yang berlipat sebesar apa disamping pada saat over supply produk pertanian bisa mempunyai masa yang lebih lama bisa dimanfaatkan.

Pendapatan tenaga kerja adalah nilai sebenarnya yang diterima oleh tenaga kerja, yang diperoleh dari hasil kali antara koefisien tenaga kerja dan upah tenaga kerja. Besarnya pendapatan tenaga kerja yang diterima oleh tenaga kerja diperoleh dari hasil kali antara koefisien tenaga kerja dengan upah ratarata tenaga kerja. Pendapatan tenaga kerja untuk mengolah sale pisang per Kilogramnya adalah $\mathrm{Rp} .7 .000,00 / \mathrm{Kg}$ dan pendapatan tenaga kerja untuk mengolah keripik pisang per kilogramnya adalah Rp.2.000,00/Kg, artinya pendapatan tenaga kerja setiap pengolahan $1 \mathrm{Kg}$ sale pisang sebesar Rp.2.000,00/Kgdan pada keripik pisang manis dan asin sebesar Rp.2.000,00/Kg. Itulah nilai rill atau sesungguhnya yang diperoleh tenaga kerja. Besarnya pendapatan sale pisang lebih tinggi dibandingkan keripik pisang hal ini dikarenakan proses pengolahan sale yang lebih rumit sehingga sebanding 
dengan upah lebih tinggi yang diterima. Besarnya pendapatan tenaga kerja pada industri pengolahan keripik yang ada di Kabupaten Banyumas berdasarkan hasil penelitian dari Mulyani (2011), yang berjudul "Nilai Tambah Agroindustri Kripik Pisang di Kecamatan Cilongok, Kabupaten Banyumas" pada tahun 2011 adalah sebesar Rp. 3979,90,-/Kg, besarnya pendapatan yang diperoleh tidak berbeda jauh dikarenakan nilai koefisien tenaga kerja sama yaitu $0,04 \mathrm{HOK} / \mathrm{kg}$ selain itu urutan jenis pekerjaan yang dilakukan juga sama sehingga upah yang diperoleh juga tidak jauh berbeda.

Pangsa tenaga kerja adalah kemampuan peningkatan pendapatan tenaga kerja setiap peningkatan satu satuan nilai tambah. Pangsa tenaga kerja untuk sale pisang adalah sebesar $18,61 \%$, pangsa tenaga kerja untuk keripik pisang rasa manis adalah $8,09 \%$, dan nilai pangsa tenaga kerja untuk keripik asin adalah $7,47 \%$, artinya setiap penambahan Rp.1 nilai tambah diperlukan penambahan tenaga kerja sebesar $18,61 \%$ pada produksi sale pisang dan $8,09 \%$, pada produk keripik pisang manis dan $7,46 \%$ pada poduk pisang asin. Besarnya pangsa tenaga kerja pada industri sejanis yang ada di Kabupaten Kebumen berdasarkan hasil penelitian Hasanah (2015), yang berjudul "Analisis Nilai Tambah Agroindustri Sale Pisang di Kabupaten Kebumen", adalah $71,66 \%$ dengan jenis pisang yang digunakan yaitu pisang raja siam kecil. Penelitain yang dilakukan di Industri Sari Gizi Kamiso Karto dan Industri yang ada di Kabupaten Kebumen memiliki pangsa tenaga kerja yang tinggi, artinya kedua industri ini dapat lebih berperan dalam memberikan pendapatan bagi pekerjanya, sehingga lebih berperan dalam mengatasi masalah pengangguran melalui pemerataan kesempatan kerja. Dengan pangsa tenaga kerja yang tinggi juga dapat membuka kesempatan yang besar dalam perekrutan tenaga kerja.

Rata-rata keuntungan yang diperoleh dari proses pengolahan sale adalah sebesar Rp.30.621,23/Kg dengan persentase keuntungan sebesar 81,39\%. Sedangkan, rata-rata keuntungan yang diperoleh dari proses pengolahan keripik pisang manis adalah sebesar Rp.22.719,28/Kg dengan presentase keuntungan sebesar $91,91 \%$, dan rata-rata keuntungan yang diperoleh dari keripik asin adalah sebesar Rp.24.786,28/Kg dengan persentase 92,53\%, Artinya setiap $1 \mathrm{Kg}$ bahan baku pisang ambon yang diolah menjadi sale pisang mampu memberikan keuntungan sebesar Rp.30.621,23/ Kg dan setiap $1 \mathrm{Kg}$ bahan baku pisang kepok yang diolah menjadi keripik pisang mampu memberikan keuntungan pisang manis sebesar Rp.22.728,24/Kg dan keripik pisang asin sebesar Rp.24.794,91/Kgdari nilai tambahnya. Besarnya keuntungan pada industri pengolahan keripik yang ada di Kabupaten Banyumas berdasarkan hasil penelitian dari Mulyani (2011), adalah sebesar Rp. 1.075,42,-/ Kg dengan tingkat keuntungan dalam persen yaitu $72,99 \%$. Tingkat keuntungan yang diperoleh dari pengolahan keripik pisang lebih tinggi dibandingkan dengan pengolahan sale pisang hal ini dikarenakan harga bahan baku keripik yang lebih 
murah, dan proses pembuatan keripik lebih mudah dibandingkan dengan proses pembuatan sale pisang.

\section{Balas Jasa Pemilik Faktor Produksi}

Hasil analisis nilai tambah juga menunjukkan margin dari bahan baku pisang ambon menjadi sale pisang dan pisang kepok menjadi keripik pisang yang didistribusikan pada keuntungan usaha, tenaga kerja dan sumbangan input lain. Artinya bahwa margin ini merupakan selisih antara nilai produk yang dihasilkan dengan harga bahan baku pisang ambon dan pisang kepok per kilogram. Setiap pengolahan $1 \mathrm{Kg}$ pisang ambon menjadi $1 \mathrm{Kg}$ sale pisang diperoleh margin sebesar Rp.39.500,00/Kg yang didistribusikan untuk masingmasing faktor yaitu keuntungan $77,52 \%$ tenaga kerja $17,72 \%$ dan input lain $4,76 \%$. Margin keuntungan pada keripik pisang manis dan asin adalah Rp. $31.200,00 / \mathrm{Kg}$ yang didistribusikan untuk masing-masing faktor yaitu keuntungan $72,82 \%$, tenaga kerja $6,41 \%$ dan input lain $20,77 \%$ pada pisang manis dan $79,44 \%$ keuntungan, $6,41 \%$ tenaga kerja dan $14,15 \%$ input lain. Margin yang didistribusikan untuk keuntungan merupakan bagian terbesar dibandingkan dengan tenaga kerja dan input lain.

Besarnya margin keuntungan pada industri pengolahan keripik yang ada di Kabupaten Banyumas berdasarkan hasil penelitian dari Mulyani (2011), yaitu sebesar Rp1.998,00/Kg Nilai ini kemudian didistribusikan untuk keuntungan pisang sebesar $\mathrm{Rp} 1.075,00 / \mathrm{Kg}$ atau 53,82\%, untuk pendapatan tenaga kerja langsung sebesar Rp398,00 atau 19,92\%, dan sumbangan input lain sebesar Rp525,00 atau 26,26\%, dari keseluruhan nilai marjin. Distribusi marjin yang terbesar adalah untuk keuntungan, keadaan ini sama dengan yang terjadi pada industri Sari Gizi Kamiso Karto yaitu tingkat keuntungan yang diperoleh paling tinggi dengan nilai $78,92 \%$. Hal yang menyebabkan tingginya keuntungan adalah harga bahan baku pembuatan keripik murah, bahan penolong yang digunakan tidak terlalu banyak dan proses pembuatan keripik pisang tidak rumit.

\section{Analisis Keberlanjutan Usaha}

\section{Keberlanjutan Usaha Sale Pisang}

Keberlanjutan usaha adalah sebuah kondisi disaat perusahaan memiliki kecukupan dana untuk menjalankan dan mengembangkan usahanya. Tujuan keberlanjutan usaha dapat diartikan sebagai maksimasi dari kesejahteraan badan usaha yang merupakan nilai sekarang badan usaha terhadap prospek masa depannya. Berdasarkan hasil perhitungan menggunanan Metode Hayami ada tiga kriteria dari keberlanjutan usaha, yaitu; rasio nilai tambah, pangsa tenaga kerja, dan tingkat keuntungan. Nilai rasio nilai tambah produk sale pisang yang diperoleh pada industri pengolahan Sari Gizi Kamiso Karto adalah 
$89,57 \%$, dari indikator keberlanjutan usaha nilai ini masuk dalam katagori tinggi, artinya penciptaan rasio nilai tambah yang dihasilkan dari mengolah buah pisang ambon menjadi sale pisang memiliki keberlanjutan usaha yang baik karena peningkatan nilai tambah yang dilihat dari besarnya rasio nilai tambah yang tinggi akan meningkatkan keuntungan bagi pemilik industri.

Hasil penelitian dari Putri (2015), yang berjudul "Analisis Nilai Tambah, Profitabilitas, dan Prioritas Faktor Keberlanjutan Usaha Pengolahan Kakao di Kabupaten Trenggalek dan Blitar", Produk yang dihasilkan adalah bubuk kakao, bubuk coklat dan coklat batangan, nilai rasio nilai tambah pada bubuk kakao adalah $58,55 \%$, bubuk coklat $88,82 \%$ dan coklat batangan $89,07 \%$. Rasio nilai tambah tertinggi didapatkan pada pengolahan kakao menjadi coklat batangan, hal ini dikarenakan bahan baku coklat batangan yang sama dengan bubuk kakao dan coklat bubuk namun mengasilkan nilai output yang lebih tinggi.

Perhitungan pangsa tenaga kerja pada produk sale pisang di Industri Sari Gizi Kamiso Karto nilai yang diperoleh adalah 18,61\% berdasarkan kriteria nilai ini masuk katagori rendah. Artinya kemampuan industri Sari Gizi Kamiso Karto dalam merekrut tenaga kerja adalah sebesar 18,61\%. Industri Sari Gizi Kamiso Karto memiliki peluang yang besar untuk menyerap banyak tenaga kerja. Hal yang dilakukan untuk meningkatkan pangsa tenaga kerja adalah dengan menambah tenaga kerja dan meningkatkan gaji pekerja setiap terdapat peningkatan nilai tambah.

Indikator keberlanjutan usaha juga dapat dilihat dari kemampuan pembentukan modal yang dapat dilihat dari besarnya tingkat keuntungan dalam (\%). Berdasarkan perhitungan menggunakan Metode Hayami Tingkat keuntungan yang dihasilkan dari produksi sale pisang sebesar 81,39\%, berdasarkan kriteria nilai ini dikatakan tinggi, tingkat keuntungan dipengaruhi oleh besarnya nilai tambah, pendapatan tenaga kerja, nilai output, sumbangan input lain, harga bahan baku dan upah tenaga kerja. Untuk lebih memperjelas berikut indikator keberlanjutan usaha pada produk sale pisang, dapat dilihat pada Tabel 3.

Tabel 3. Keberlanjutan Usaha Sale Pisang

\begin{tabular}{ccc}
\hline No. & Indikator Keberlanjutan Usaha & Skor Sale Pisang \\
\hline 1. & Rasio Nilai Tambah & 3 \\
2. & Pangsa Tenaga Kerja & 1 \\
3. & Tingkat Keuntungan & 3 \\
\hline & Total & 7 \\
\hline
\end{tabular}

Sumber: Diolah dari data primer 2018

Untuk melihat tingkat keberlanjutan usaha Pengolahan Pisang Sari Gizi Kamiso Karto dapat dilihat dari total nilai ketiga kriteria indikator keberlanjutan usaha yaitu dilihat dari rasio nilai tambah, pangsa tenaga kerja, dan tingkat keuntungan, dengan cara menjumlahkan nilai yang diperoleh setiap skor yang 
ada. Nilai pada setiap kriteria adalah; rendah (1), sedang (2) dan tinggi (3). Usaha dapat dikatakan berlanjut apabila nilai total skor berada pada 6-9 sedangkan untuk usaha yang tidak berlanjut berada pada nilai skor 3-5. Berdasarkan perhitungan total nilai dari ketiga kriteria indikator keberlanjutan usaha pada produk sale pisang memiliki nilai 7 , artinya usaha ini dapat dikatakan berlanjut karena nilai berada diantara 6-9 sesuai dengan kriteria. Tingkat keberlanjutan usaha dari usaha pengolahan pisang ambon menjadi sale pisang ini memiliki kebelanjutan usaha yang baik.

\section{Keberlanjutan Usaha Keripik Pisang}

Rasio nilai tambah produk keripik pisang manis yang diperoleh pada industri pengolahan Sari Gizi Kamiso Karto adalah 74,91\% dan keripik pisang asin $81,17 \%$, dari indikator keberlanjutan usaha, nilai ini masuk dalam katagori tinggi, artinya penciptaan rasio nilai tambah yang dihasilkan dari mengolah buah pisang kepok menjadi keripik pisang manis dan asin memiliki keberlanjutan usaha yang baik untuk dikembangkan kedepannya, hal ini dikarenakan harga bahan baku untuk pembuatan keripik yang murah, jumlah bahan penolong yang tidak terlalu banyak dan proses pengerjaan keripik yang tidak rumit. Proses pembuatan tersebut kemudian menghasilkan nilai tambah dan rasio nilai tambah yang tinggi, itulah yang membuat tingkat keberlanjutan usaha keripik pisang baik untuk semakin dikembangkan kedepannya.

Indikator keberlanjutan usaha yang selanjutnya adalah kemampuan penciptaan lapangan kerja yang dapat dilihat dari besarnya pangsa tenaga kerja. Dari hasil perhitungan pangsa tenaga kerja pada produk keripik pisang manis di Industri Sari Gizi Kamiso Karto nilai yang diperoleh adalah 8,09\% dan keripik pisang asin $7,47 \%$, berdasarkan kriteria nilai ini masuk katagori rendah. Artinya kemampuan industri Sari Gizi Kamiso Karto dalam merekrut tenaga kerja adalah sebesar $8,09 \%$ dan $7,47 \%$. Hal ini dikeranakan antara pekerjaan yang harus diselesaikan dengan jumlah tenaga kerja yang bekerja telah sesuai, tidak perlu penambahan jumlah tenaga kerja yang banyak apabila tidak terjadi peningkatan nilai tambah, hal ini dikarenakan tenaga kerja yang bekerja sudah terampil dalam mengolah keripik pisang.

Berdasarkan perhitungan menggunakan Metode Hayami Tingkat keuntungan yang dihasilkan dari produksi keripik pisang manis sebesar 91,91\% dan $92,53 \%$ keripik pisang asin, berdasarkan kriteria nilai ini dikatakan tinggi, tingkat keuntungan menggambarkan besarnya keuntungan yang diperoleh dari hasil pengolahan pisang kepok menjadi keripik pisang manis dan asin. Hal yang menyebabkan tingginya tingkat keuntungan adalah tingginya nilai tambah yang mampu dihasilkan dari pengolahan pisang kepok menjadi keripik pisang. Perbandingan antara harga bahan baku, jumlah sumbangan input lain, upah tenaga kerja dan harga output telah sesuai sehingga menciptakan tingkat keuntungan yang tinggi dan keberlanjutan usaha yang baik. Untuk lebih 
memperjelas keberlanjutan usaha pada produk sale pisang, dapat dilihat pada Tabel 4, menurut indikator keberlanjutan usaha.

Tabel 4. Keberlanjutan Usaha Keripik Pisang Manis dan Asin

\begin{tabular}{cccc}
\hline No. & $\begin{array}{c}\text { Indikator Keberlanjutan } \\
\text { Usaha }\end{array}$ & $\begin{array}{c}\text { Skor Keripik } \\
\text { Pisang Manis }\end{array}$ & $\begin{array}{c}\text { Skor Keripik } \\
\text { Pisang Asin }\end{array}$ \\
\hline 1. & Rasio Nilai Tambah & 3 & 3 \\
2. & Pangsa Tenaga Kerja & 1 & 1 \\
3. & Tingkat Keuntungan & 3 & 3 \\
\hline \multicolumn{4}{r}{ Total } \\
\hline
\end{tabular}

Sumber: Diolah dari data primer 2018

Berdasarkan perhitungan total nilai dari ketiga kriteria indikator keberlanjutan usaha pada produk keripik pisang memiliki nilai 7, artinya usaha ini dapat dikatakan berlanjut karena nilai berada diantara 6-9 sesuai dengan kriteria. Tingkat keberlanjutan usaha dari usaha pengolahan pisang kepok menjadi keripik pisang ini memilik kebelanjutan usaha yang baik.

\section{SIMPULAN DAN SARAN}

\section{Simpulan}

Berdasarkan hasil penelitian dan pembahasan yang telah dilakukan, maka dapat ditarik kesimpulan sebagai berikut :

1. Besarnya nilai tambah yang dihasilkan dari pengolahan pisang ambon menjadi sale pisang dan pisang kepok menjadi keripik pisang pada Industri Sari Gizi Kamiso Karto, yaitu sebesar : Rp.37.621,23/Kg dengan rasio nilai tambah $89,57 \%$ pada produk sale pisang, Rp.24.719,28/Kg dengan rasio nilai tambah $74,91 \%$ pada produk keripik pisang manis dan Rp.26.786,28/Kg dengan rasio nilai tambah $81,17 \%$ pada produk keripik pisang asin.

2. Tingkat keberlanjutan usaha pada Industri Sari Gizi Kamiso Karto yang dihitung berdasarkan hasil dari perhitungan dengan Metode Hayami, digunakan tiga kriteria keberlanjutan usaha, yaitu: rasio nilai tambah, pangsa tenaga kerja, dan tingkat keuntungan didapatkan hasil, bahwa : produk sale pisang dan keripik pisang rasa manis dan rasa asin, memiliki tingkat keberlanjutan usaha yang tinggi dan baik untuk dikembangkan kedepannya.

\section{Saran}

Pisang ambon dan pisang kepok adalah pisang yang memiliki produktivitas yang tinggi di wilayah Rejang Lebong, karena memiliki nilai ekonomi yang rendah pada saat kelebihan produksi maka diperlukan upaya 
untuk pengolahan lebih lanjut agar daya simpannya lebih lama. Salah satu cara untuk meningkatkan daya simpan yaitu dengan diolah menjadi sale pisang dan keripik pisang karena memiliki nilai tambah yang baik.

Industri Sari Gizi Kamiso Karto sebaiknya terus mempertahankan usahanya karena, pengolahan pisang di industri ini mampu menghasilkan nilai tambah yang tinggi dibandingkan di tempat lain.

\section{DAFTAR PUSTAKA}

Anggraini Ratih. 2013. Analisis Usaha dan Nilai Tambah Industri Olahan Pisang di Kota Palu Provinsi Sulawesi Tengah. Universitas Muhammadiyah Yogyakarta. Yogyakarta

Bagus Ida, Eka .A, dan Ida A.K.M. 2016. Analisis Nilai Tambah (Value Added) Buah Pisang Menjadi Kripik Pisang Di Kelurahan Babakan Kota Mataram (Studi Kasus Pada Industri Rumah Tangga Kripik Pisang Cakra ). Ganec Swara. 10(1):94-98.

Lagitan (1994). Analisis Nilai Tambah Produk Minuman Segar Susu Kedelai. Jurusan Sosial Ekonomi Pertanian IPB Bogor.

Hayami, Y. 1987. Agricultural Marketing and Processing in Upland Java: A Perspective From A Sunda Village. CGPRT, Bogor.

Mulyani, A., Dindy Darmawati Putri, Ratna Satriani. 2011. Nilai Tambah Agrosindustri Kripik Pisang Di Kecamatan Cilongok, Kabupaten Banyumas. Program Studi Agribisnis, Fakultas Pertanian, Universitas Jenderal Sudirman. Purwokerto, Jawa Tengah

Purnamasari, R. 2017. Analisis Nilai Tambah dan Resiko Usaha Agroindustri Emping Melinjo Skala Rumah Tangga di Desa Meok Kecamatan Enggano Kab. Bengkulu Utara. Skripsi. Fakultas Pertanian Universitas Bengkulu. Bengkulu (tidak dipublikasikan).

Putri Vitalia. 2015. Analisis Nilai Tambah, Profitabilitas, dan Prioritas Faktor Keberlanjutan Usaha Pengolahan Kakao di Kabupaten Trenggalek dan Blitar. Tesis. Fakultas Pertanian. Institude Pertanian Bogor

Sugiyono. 2013. Metode Penelitian Pendidikan : Pendekatan Kuantitatif, Kualitatif dan R\&D. Bandung: Penerbit Alfabeta

Uswatun H, Mayshuri dan Djuwari. 2014. Analisis Nilai Tambah Agroindustri Sale Pisang di Kabupaten Kebumen. Ilmu Pertanian. 18(3): 141 - 149.

Usrtriyana, I.N.G., Artini, N.W.P. 2018. Analisis Indeks Keberlanjutan Usahatani Cabai Di Kabupaten Bangli. Jurnal Sosial Ekonomi Pertanian dan Agribisnis SOCA. 12(1):99-108. 